\title{
Acquired Factor VII Deficiency
}

National Cancer Institute

\section{Source}

National Cancer Institute. Acquired Factor VII Deficiency. NCI Thesaurus. Code $C 131625$.

An acquired coagulation disorder characterized by the partial or complete absence of factor VII activity in the blood. 